\title{
13
}

\section{Compositional analysis of Fijian ceramics}

\author{
Geoffrey Clark \\ Department of Archaeology and Natural History, The Australian National University \\ Douglas Kennett \\ Department of Anthropology, The University of Oregon
}

\section{Introduction}

The varied geological setting of the Fiji Islands gave rise to clays and temper sands that were combined by prehistoric potters to manufacture ceramics with distinctive constituents. Compositional analysis of pottery can be used to identify non-local sherds, and when comparative geochemical information is available, to delineate a potential ceramic source locale for local and exotic ceramics. The technique of examining mineral and non-mineral materials entrained in clays or added to clays by prehistoric potters was first used by Curtis (1951), who analysed 26 pot sherds excavated by Edward Gifford from the Navatu and Vuda sites in northern Viti Levu. Comprehensive petrographic study of Fijian sherds has been made by Dickinson (1971, 1973, 1980, 1998, 2001, 2006) and Best (1984), with additional work by Petchey (1995), Aronson (1999) and Bentley (2000). Fijian pot clays have been analysed by Best (1984:359-367, Appendix G) and Petchey (1995:142) using X-Ray Florescence and the Electron Microprobe. Kennett et al. (2004) and Bentley (2000) have investigated the chemical composition of Fijian ceramics with Neutron Activation Analysis (NAA) and Microwave Digestion Inductively Coupled Plasma Mass Spectrometry (MD-ICP-MS), and Cochrane (2004) employed Laser Ablation Inductively Coupled Plasma Mass Spectrometry (LA-ICP-MS) on ceramics from the Yasawa Islands.

Petrographic analysis is a potent technique able to reveal pottery transfer over short and long distances, with Fijian ceramics identified from as far afield as Rotuma, Tuvalu, Tokelau, Tonga and Samoa (Dickinson 2006:117-118). The petrographic study of thin sections is time consuming, however, and defining the origin of temper sands requires considerable skill and a 
detailed knowledge of island geology and geomorphology. Consequently, the number of sherds examined from a particular prehistoric site is often small in relation to the size of the excavated assemblage. It has also been difficult for archaeologists to establish just how common exotic sherds actually are in an assemblage, and whether temper sands were associated with particular vessel forms or decorative techniques (see Best 1984). It has also been argued that non-local ceramics were usually transported as already manufactured containers, rather than as raw materials, although the movement of temper sands has been recorded in several archaeological sites (Best 1984:352; Dickinson 1998:266).

The EPF ceramic collections were analysed using two methods aimed at examining prehistoric interaction in the Fiji Islands. First, our approach built on the proven technique of petrographic examination of sherds by William Dickinson, reinforced by optical examination of three sherd collections under low-power magnification to examine potential linkages between temper, surface decoration, vessel form and ceramic age.

Second, broader patterns of prehistoric interaction were examined through an MD-ICPMS analysis of sherds from nine sites (Figure 138). In petrography, the mineral grains added or entrained in a clay are identified, but the approach cannot specify whether a sherd clay is exotic, or whether exclusively calcareous-tempered sherds are imports. Chemistry-based MDICP-MS measures the bulk element composition of the clay and the temper in a sherd sample. The chemical analysis of sherds using methods such as NAA, MD-ICP-MS and LA-ICDMS is appealing to archaeologists because relatively large numbers of ceramic samples can be quickly analysed, compared with petrography, and because the recognition of non-local sherds using element data does not necessarily require a detailed knowledge of archipelago geology.

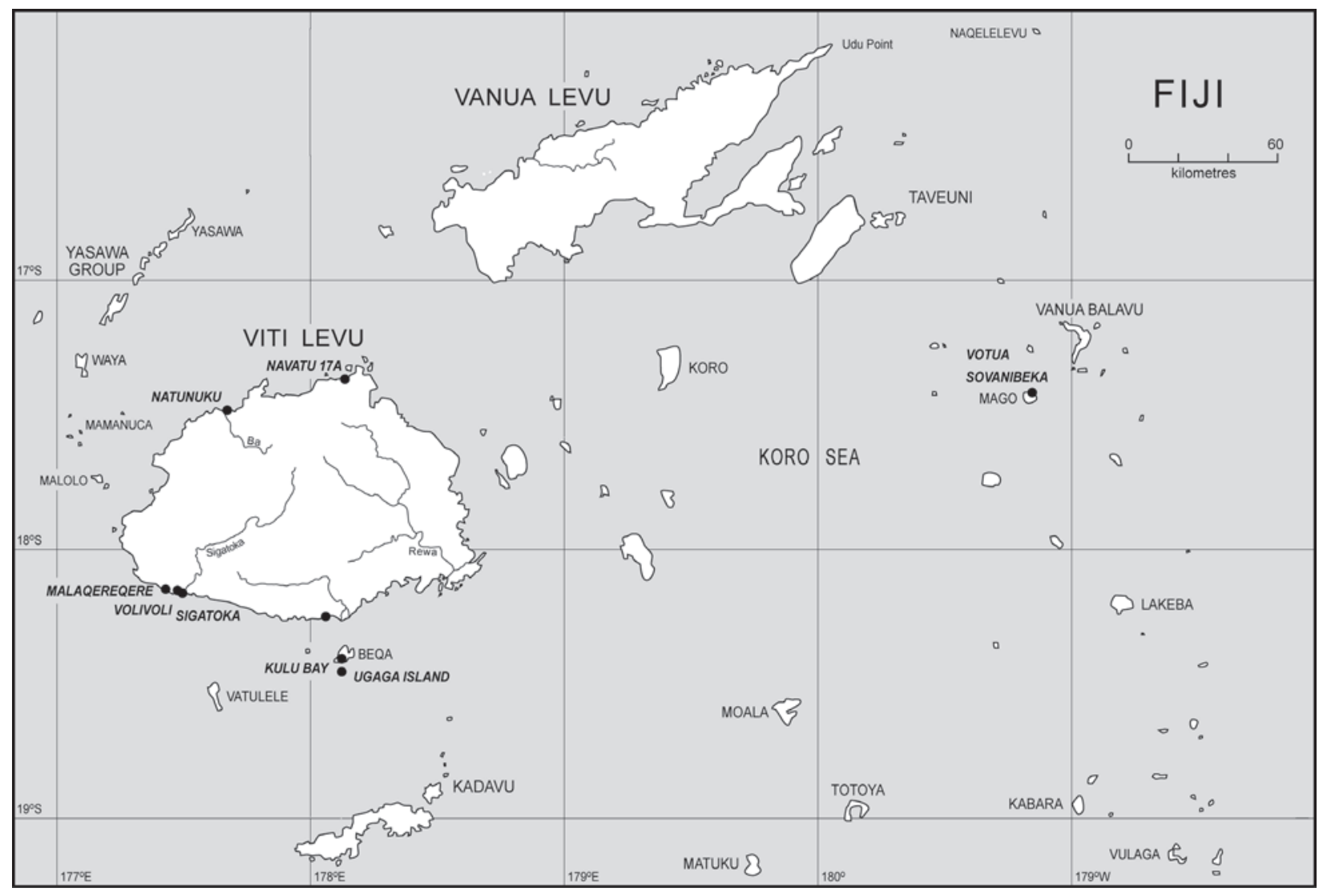

Figure 138. Location of EPF ceramic collections analysed with petrography and MD-ICP-MS. 
To examine the correlation between petrographic and chemical results, ceramics from Navatu, Ugaga and Karobo examined with petrology, including identified non-local specimens, were also analysed with MD-ICP-MS.

The MD-ICP-MS results from Ugaga Island and Kulu Bay showed that sherds from the two sites were chemically distinct from one another, while Dickinson's petrology examination identified sherd tempers at both sites as compatible with an origin on Beqa Island, and consistent with the transport of pottery from Kulu Bay and other places on Beqa to the small islet of Ugaga, 2-3 km from the Beqa coast. The chemical signature of sherds may be affected by several factors, including the quantity and number of tempers added to a clay, the duration and intensity of firing, and the chemistry of the depositional environment. Analysis of MD-ICP-MS results from Ugaga Island and Kulu Bay suggest that burial conditions may have changed the element concentrations in pot sherds from one or both sites, and caution should attend multisite analysis of ceramics based purely on chemical data.

\section{Ceramic samples}

A total of 98 sherds from eight archaeological sites was examined in thin section by William Dickinson (see Dickinson 2006 for details), who identified the mineralogy of temper sands and established megascopic guidelines for separating sherds into local temper groups. A total of 896 rim and body sherds from three sites - Navatu 17A, Ugaga and Karobo - was sectioned with a diamond saw, and the cleaned sections examined under low-power magnification and identified to one of Dickinson's megascopic temper groups (Table 60). A total of 219 sherds from nine sites was analysed with chemistry-based MD-ICP-MS, extending an earlier study of 43 Lapitaage sherds from the Ugaga and Kulu sites reported by Kennett et al. (2004).

Table 60. Ceramic samples from Fijian archaeological sites analysed with petrology, low-power microscopy and chemical methods.

\begin{tabular}{|c|c|c|c|}
\hline Site Location & Petrography: Temper sand & Macroscopic: Temper sand & MD-ICP-MS: Clay + temper \\
\hline \multicolumn{4}{|c|}{ Viti Levu: South Coast } \\
\hline Sigatoka & 1 & & 10 \\
\hline Volivoli II + III & & & 24 \\
\hline Malaqereqere & & & 14 \\
\hline Karobo & 10 & 238 & 15 \\
\hline \multicolumn{4}{|c|}{ Viti Levu: North Coast } \\
\hline Natunuku & 26 & & 31 \\
\hline Navatu 17A & 26 & 253 & 31 \\
\hline \multicolumn{4}{|l|}{ Offshore Islands } \\
\hline Kulu Bay, Beqa & 10 & & 26 \\
\hline Ugaga Island, Beqa & 17 & 405 & 38 \\
\hline Votua, Mago & 5 & & 27 \\
\hline Sovanibeka, Mago & 3 & & 3 \\
\hline Total & 98 & 896 & 219 \\
\hline
\end{tabular}




\section{Petrographic and macroscopic examination of sherds from Navatu, Ugaga and Karobo}

Generically distinctive temper provenances are empirically definable from an island's geotectonic environment. Indigenous pottery can be inferred from the similarity of temper sands to local island bedrock, while pottery transfer can be identified from the occurrence of exotic temper sands that could not be derived from local island bedrock. The texture of temper assessed from the degree of grain sorting and angularity indicates whether prehistoric potters collected sands from beach, stream or non-coastal terrestrial environments. Temper sands in sherds were examined in thin section, with frequency counts of individual mineral types made from a total of 300-400 identified grains per section (see Dickinson 1998, 2006). Calcareous grains are a common component of many sherd assemblages in Oceania that cannot be used to infer provenance because reef characteristics are similar throughout the region.

Megascopic examination of temper grains is inherently less accurate than petrography since the mineral assemblage is not identified, and the appearance of related tempers may be highly variable as proportions of associated grains of different colouration vary (Dickinson 1998:273). The approach has the advantage, however, that larger sherd samples can be examined to assess whether ceramic tempers vary systematically by excavation stratigraphy/unit, or by vessel form and type of surface decoration. Dickinson's petrographic study identified the temper groups present in three assemblages - Navatu, Ugaga and Karobo - and recorded the megascopic criteria associated with each. Sherds examined megascopically were sectioned with a diamond lapidary saw, and identified to one of Dickinson's temper groups using the megascopic guidelines. Calcareous inclusions were tested with $10 \% \mathrm{HCl}$ and the strength of the reaction recorded on a scale of 1 (low) to 3 (high).

\section{Navatu 17A temper groups}

Temper sands from Navatu 17A sherds consist of a spectrum of related basaltic sands that were subdivided by Dickinson into four subgroups depending on the proportions of plagioclase feldspar and ferromagnesian grains, and the quantity and mineralogy of the extrusive and intrusive igneous rock fragments. Most temper sands were subangular to subrounded, fine to coarse in size, and moderately to well sorted. Calcareous grains occurred in sherds from all temper subgroups at a frequency of $1 \%$ to $5 \%$. Temper variants are likely to represent local sands, collected from streams and beaches close to the Navatu 17A site, that eroded from the Ba Volcanic Group (Seeley and Searle 1970).

\section{Standard (non-placer and non-lithic)}

The standard tempers contain relatively even proportions of plagioclase feldspars and ferromagnesian grains (mean 22\% and 23\% respectively), followed by hornblende (10\%). Hypabyssal and volcanic rock fragments have a combined frequency mean of $34 \%$. Olivine, epidote and opaque iron oxide are under $10 \%$, while quartz and biotite are rare or absent $(\leq 1 \%)$.

\section{Pyroxenic placer (PP)}

In the PP temper, pyroxene is dominant, varying from $40 \%$ to $82 \%$ (mean $75 \%$ ) of counted grains. Variation is considered to be due to the degree of beach placering. Plagioclase feldspars are present in amounts generally less than $10 \%$, as are other minerals such as hornblende, olivine and opaque iron oxide. Quartz, epidote and biotite constitute 1\% or less of the grain types. Hypabyssal fragments are also under $10 \%$, and volcanic rock fragments range from $6 \%$ to $21 \%$. 


\section{Opaque/Lithic rich (OL)}

In these temper variants, the plagioclase feldspars $(\mathrm{F})$ are significantly more abundant than clinopyroxene $(\mathrm{C})$ (mean $\mathrm{F} / \mathrm{F}+\mathrm{C}=0.68$ ). The variants are distinguished in thin section by the frequency of opaque iron oxides (16\% versus 3\%) and rock fragments (59\% versus $26 \%$ ). Hornblende, olivine, epidote and biotite are present in trace or low frequencies $(\leq 3 \%)$.

Megascopically, it is difficult to distinguish between the opaque and lithic-rich temper variants, and these are combined into a single subgroup (OL) using the proportion of plagioclase feldspar/lithic to ferromagnesian grains as the main selection criterion. Subgroup identification using low magnification on a highly variable and allied temper spectrum was difficult and the megascopic temper identifications should be tested by additional petrographic work.

\section{Navatu: Vessel form/decoration versus temper}

Rim sherds used to establish vessel form $(\mathrm{n}=33)$ and 220 body sherds were sectioned and identified under low-power magnification to one of Dickinson's temper subgroups. The majority of these sherds were from Layer $4(\mathrm{n}=140)$ with 80 sherds from the Layer 1 assemblage. Comparison of vessel form with temper subgroup reveals little association in Layer 1 (Table 61). The clearest trend is the apparent restriction of the opaque and lithic-rich variants to the Layer 4 assemblage, where they were used in making double-spouted vessels and decorated bowls, but not apparently in the manufacture of utilitarian cooking jars with everted rims. The double-spouted containers, some with a stirrup handle, are complex vessel forms likely to have been drinking vessels for high-status individuals (Clark and Sorovi-Vunidilo 1999).

\section{Navatu non-local tempers}

In the sample of 220 sectioned body sherds, only one sherd was identified in the Layer 1 assemblage (NAV-1015) as having an unusual spectrum of temper grains and it was sent to Dickinson. Petrographic examination shows it to contain a non-local temper. Reappraisal of the Gifford excavation sherds by Dickinson reveals another sherd with an anomalous temper from a context equivalent to Layer 4 (No. 11-8764).

The temper in NAV-1015 contains moderately sorted, subangular grains of fine sand size that might represent natural temper sands embedded in the clay paste. Quartz and plagioclase feldspars are abundant (30\% and 34\% respectively), with pyroxene, hornblende, epidote and opaque iron oxide present in amounts under $10 \%$. A specific origin for this sherd could not be determined, but the mineral suite is consistent with derivation from the dissected orogen of interior or southern Viti Levu. The sherd almost certainly dates to the past 600 years, considering its location (Trench B: 40-50 cm depth) and incised surface decoration.

The second non-local Navatu sherd (No. 11-8764) has a temper composed of subrounded to subangular, fine to medium-grained sand. Quartz, which in local Navatu sherds occurs at a frequency of $1 \%$ or less, is present at $7 \%$. Total plagioclase $(16 \%)$ and clinopyroxene $(11 \%)$ values is lower than local Navatu sherds, while olivine is present in trace amounts. Biotite levels are slightly higher at $2 \%$. Microlitic to felsitic volcanic rock fragments were abundant (41\%). Gifford (1951:Plate 22, z) illustrates this rim sherd which was decorated with three rows of oval end-tool impressions on the rim, and cross-hatch relief on the body.

The temper belongs to the dissected orogen type derived from the Wainimala orogen exposed in the interior of Viti Levu, and the Rewa River watershed of eastern Viti Levu is a likely location. Sherd No. 11-8764 was recovered by Gifford from Rectangle EF3-4: 250-265 $\mathrm{cm}$ depth, which suggests it dates to ca.1000-1500 cal. BP. 
Table 61. Navatu temper groups by vessel form and surface modification.

\begin{tabular}{|c|c|c|c|}
\hline \multicolumn{4}{|l|}{ Navatu Layer 1} \\
\hline Vessel form & \multicolumn{2}{|c|}{ Standard Non-Placer } & Pyroxenic Placer \\
\hline Jar - everted rim & \multicolumn{2}{|l|}{8} & 2 \\
\hline Bowl - everted rim & \multicolumn{2}{|l|}{2} & - \\
\hline Single orifice $\leq 10 \mathrm{~cm}$ & \multicolumn{2}{|l|}{1} & 1 \\
\hline Total & \multicolumn{2}{|l|}{11} & 3 \\
\hline Decoration & Standard Non-Placer & Pyroxenic Placer & Other \\
\hline Shell impressed & 59 & 6 & - \\
\hline Incised symmetric & 4 & - & 1 \\
\hline Appliqué & 4 & 1 & - \\
\hline Side tool (shell) & 5 & - & - \\
\hline Total & 72 & 7 & 1 \\
\hline \multicolumn{4}{|l|}{ Navatu Layer 4} \\
\hline Vessel form & Standard Non-Placer & Placer Pyroxenic & Opaque/ Lithic \\
\hline Jar - everted rim & 5 & 2 & - \\
\hline Bowl - everted rim & - & 1 & - \\
\hline Bowl - inverted rim & 1 & 1 & 1 \\
\hline Bowl - inverted 'flange' rim & - & 1 & 2 \\
\hline Single orifice $\leq 10 \mathrm{~cm}$ & 1 & - & - \\
\hline Double spout and stirrup handle & 1 & - & 3 \\
\hline Total & 8 & 5 & 6 \\
\hline Decoration & Standard Non-Placer & Placer Pyroxenic & Opaque/ Lithic \\
\hline Cross-hatch relief & 37 & 8 & 5 \\
\hline Parallel-rib relief & 21 & 7 & 4 \\
\hline Curvilinear relief & 34 & 4 & - \\
\hline Side tool (rounded) & 4 & 2 & 4 \\
\hline End tool & 9 & 1 & - \\
\hline Total & 105 & 22 & 13 \\
\hline
\end{tabular}

\section{Ugaga Island temper groups}

Three temper groups were identified in the Ugaga Island assemblage by Dickinson, with the same temper groups found in the ceramic assemblage excavated from the nearby heavily-disturbed Lapita site at Kulu Bay on Beqa Islands. The temper sands are mineralogically and texturally varied, indicating pottery transfer to Ugaga Island from multiple locations.

Quartzose-Feldspathic (QF)

The QF temper grains are fine to coarse in size and subrounded to subangular. Plagioclase feldspar grains are abundant (mean 31\%), with clinopyroxene (13\%) and hornblende (8\%) in roughly equal proportions. Subordinate amounts of quartz, epidote and micro-angular rock 
fragments from extrusive sources are also present in amounts generally less than $10 \%$.

Calcareous grains were not identified in the sherds examined by Dickinson, but small fragments of reef detritus are identified in the sectioned sample. A likely origin for the QF temper sands is Kulu Bay, which is surrounded by atypical exposures of feldspar-rich shoshonitic rock, but in the absence of an examination of beach sands from Kulu Bay, a south Viti Levu origin for these sherds remains a possibility. Shoshonite also outcrops in the north and south of Yanuca Island in the Beqa lagoon (Band 1968:27) and some sherds with the QF temper could derive from Viti Levu and Yanuca Island, as well as Kulu Bay.

Pyribole rich (PY)

Temper sands in the PY temper group are fine-to-medium, moderately sorted, with subangular to subrounded form. Pyroxene (35-50\%) and hornblende (20-31\%) are prevalent, followed by opaque iron oxide and small amounts of plagioclase feldspar $(<10 \%)$ and volcanic rock fragments. Quartz, epidote and calcareous grains are absent or rare. Outcrops of hornblendeaugite andesite occur at Vaga Bay on Beqa Island (about $2 \mathrm{~km}$ from Kulu Bay), where there are also dykes of hornblende dolerite, and at the southern end of Malumu Bay. However, Band (1968:37) notes that hornblende was virtually absent at Malumu Bay, but common at Vaga Bay. The green-to-brown pleochroism of the hornblende grains in the temper sands is similar to that recorded for Vaga Bay, indicating the likelihood of a Beqan origin.

Mixed placer (MP)

Calcareous grains of reef detritus vary from $9 \%$ to $60 \%$ of the counted grains. The $9 \%$ value is probably low and due to weathering of embedded shell fragments. The mineral temper is well sorted, subrounded-to-rounded, and fine-to-medium grained. The main mineral is clinopyroxene (19-65\%), followed by opaque iron oxide (2-35\%), volcanic rock fragments, and plagioclase feldspars. Hornblende and biotite are present in small amounts $(\leq 3 \%)$. A Beqan source, excluding Kulu and Vaga Bays, is considered likely for this temper in view of the significant pyroxene and low hornblende content.

\section{Ugaga: Vessel form/decoration versus temper}

A total of 405 rim and body sherds were sectioned and identified to one of Dickinson's temper groups (Table 62). The QF temper is common in jars with abruptly thickened rims, also known as 'collar rims' or 'expanded rims', while PY and MP tempers are frequently associated with utilitarian jars with everted rims. A dentate-stamped dish with a flat base has the QF temper, suggesting the restriction of this temper type to the Lapita period. In post-Lapita times, the MP temper became increasingly popular and was mixed with clay to make jars with everted rims.

Temporal change in the use of QF temper is clearly illustrated in the sample of 290 sectioned body sherds with distinctive surface modification. About $82 \%$ of all dentate-stamped sherds have the quartzose temper, supporting the inference that it is restricted to the first ceramics brought to Ugaga Island. Carinated sherds and those of unspecified form described as lugs or stands also yield a high proportion of QF sherds (12/19 or 63\%), suggesting most date to the Lapita period ca. 3000-2600 cal. BP. There is a slight indication in the temper data for a decline in PY and an increase in MP tempers in post-Lapita sherds. Dented and parallel-rib relief sherds have PY values of 30-34\%, whereas the sherds with diamond and square relief have lower PY values, at $16-17 \%$. 
Table 62. Ugaga temper groups by vessel form and surface modification.

\begin{tabular}{|c|c|c|c|c|}
\hline Vessel form & QF & PY & MP & Non-local \\
\hline Jar - everted rim & 4 & 17 & 48 & 1 \\
\hline Jar - abruptly thickened rim & 9 & 3 & 6 & - \\
\hline Bowl - everted rim & 2 & 3 & 8 & - \\
\hline Bowl - inverted rim & - & 1 & 5 & - \\
\hline Bowl - inverted 'flange' rim & - & 1 & 2 & - \\
\hline Dish - flat base & 1 & - & - & - \\
\hline Double spout & - & 1 & - & - \\
\hline Double spout and stirrup handle & - & - & 2 & - \\
\hline ?Vessel form & - & - & - & 1 \\
\hline Total & 16 & 26 & 71 & 2 \\
\hline \multicolumn{5}{|l|}{ Surface modification } \\
\hline Body sherds & QF & PY & MP & Non-local \\
\hline Dentate stamped & 41 & 2 & 6 & 1 \\
\hline Dents & - & 9 & 21 & - \\
\hline Parallel-rib relief & - & 31 & 59 & - \\
\hline Square relief & - & 5 & 25 & - \\
\hline Diamond relief & - & 14 & 75 & 1 \\
\hline Total & 41 & 61 & 186 & 2 \\
\hline
\end{tabular}

\section{Ugaga Island non-local tempers}

Six sherds in the megascopic sample did not appear to match any of the temper groups, and were sent to Dickinson for examination. Four of the sherds proved to be from two provenance areas beyond Beqa Island. The sherd description and provenance, and the inferred source of the tempers is given in Table 63.

Two sherds had an unusual temper that required staining of the thin sections to determine their mineralogy. Sherds UGA-1158 and UGA-2064 are quartz rich (56\%), with significant plagioclase feldspars (38\%) and small quantities of felsitic volcanic rock fragments, opaque iron oxide and clinopyroxene. The temper sand is moderately sorted (fine to coarse sand size), and grains are subangular to subrounded. UGA-1158 also contains calcareous reef fragments. On the available geological evidence, and in the absence of a comprehensive Vanua Levu temper suite, Dickinson suggests a source from the Udu Volcanic Group on the northern Vanua Levu peninsula. The quartz-rich Ugaga sherd (UGA-1158) with dentate stamping is undoubtedly of an early age and was brought to the island with the first pottery assemblages. Two more sherds with the same decoration and temper are identified, but the vessel form(s) could not be determined.

The temper grains in two sherds (UGA-1106 and UGA-2079) indicate an origin from the southern coast of Viti Levu (or from an interior drainage leading to the south coast). These sherds contain moderately sorted, subangular to subrounded quartzose temper sands that are likely to be of stream origin and of dissected orogen type. The ratio of quartz $(\mathrm{Q})$ to plagioclase feldspar $(\mathrm{F})$ is similar for both sherds $(\mathrm{Q} / \mathrm{Q}+\mathrm{F}=0.64$ and 0.66$)$, but they differ from each other in the amount of ferro-magnesian and intrusive igneous rock fragments. The presence of 
overlapping, deep and irregular cross-hatch paddle impressions on UGA-1106 suggests a likely time of transport in the mid-sequence (ca. 1700-1200 BP), but the age of the plain rim sherd, UGA-2079, cannot be determined.

Table 63. Ugaga sherds identified by petrology as having a non-local temper.

\begin{tabular}{|c|c|c|c|}
\hline Description & Sherd No. & Square and Depth $(\mathrm{cm})$ & Inferred origin \\
\hline $\begin{array}{l}\text { Body sherd with deep irregular cross-hatch relief, } 5.9 \mathrm{~mm} \text { thick. } \\
\text { Blackened interior surface. }\end{array}$ & UGA-1106 & M6: 20-30 & South coast or inland Viti Levu, ?Rewa Delta \\
\hline Plain rim with flat-rounded lip. & UGA-2079 & F8: $30-40$ & South coast or inland Viti Levu, ?Rewa Delta \\
\hline Body/rim sherd with dense dentate stamping, $11.7 \mathrm{~mm}$ thick. & UGA-1158 & $\mathrm{L} 5: 20-30$ & Udu Point, northeast Vanua Levu \\
\hline $\begin{array}{l}\text { Plain rim with pointed lip, } 8.7 \mathrm{~mm} \text { thick. Joins to dentate- } \\
\text { stamped sherd UGA-906. }\end{array}$ & UGA-2064 & F8: $10-20$ & Udu Point, northeast Vanua Levu \\
\hline
\end{tabular}

\section{Karobo temper groups}

The local Karobo temper in five thin-sectioned sherds (KAR-1A, 3A, 4A, 5A, 7A) is a moderately sorted, subangular to subrounded quartz-bearing sand of varied mineralogy and fine to coarse grain size. Quartz (average 29\%) and plagioclase (average 24\%) are abundant, while hornblende (average $8 \%$ ) is generally greater than clinopyroxene (average 1\%). Opaque iron oxide and epidote are present at $10 \%$ or less, and rock fragments, including those from sedimentary/ metasedimentary deposits, are common (average 28\%). Fragments of volcanic rock and red latteritic soil, some of which are more than $1 \mathrm{~cm}$ in length, are common in the megascopic examination of Karobo sherds, as are fragments of a pale white chert/metachert. No calcareous grains are recorded reacting with $\mathrm{HCl}$, although recessive pits in sherds could indicate their former presence. On textural and mineralogical grounds, Dickinson considers that the indigenous Karobo tempers do not derive from beaches, and were probably collected from a variety of local drainages tapping the Wainimala bedrock near Karobo. One sherd (KAR-8A) contains small amounts of weathered volcanic rock as temper, which may represent fluvial debris transported from Wainimala exposures near Karobo.

\section{Karobo: Vessel-decoration versus temper}

Sectioning and examination of temper grains in 220 body sherds and 18 vessel rims does not reveal a strong association between temper type and vessel form, or type of surface modification (Table 64). There is no evidence for the spatial restriction of temper types to different excavation areas. The available site information does not allow temper types, however, to be correlated with stratigraphy. Around $81 \%$ of body sherds have the QF temper of dissected orogen type expected from drainages near the site, such as the Taunovo, Waisese and Wainiyabia. Sherds with sparse temper sands make up 3\% of the sample, and have a similar appearance to the sherd containing weathered volcanic rock fragments (VRF temper).

\section{Karobo non-local tempers}

Megascopic examination of Karobo sherds revealed the presence of another reasonably common non-quartzose temper group, and four sherds from this group were sent to Dickinson. Petrographic identification of the mineral suite suggests importation of temper sands from one or two locations.

The non-local temper in three sherds (KAR-155, 204, 811) consists of a well-sorted, subangular to subrounded placer sand of beach origin. Quartz is rare or absent and clinopyroxene is 
Table 64. Karobo temper groups by vessel form and surface modification.

\begin{tabular}{lccc}
\hline Vessel form & Quartzose Feldspathic & Pyroxenic Placer & Opaque 0xide \\
\hline Jar - everted rim & 7 & 3 & - \\
Bowl - everted rim & 1 & 1 & - \\
Bowl - inverted 'flange' rim & 1 & - & 1 \\
Platter & 3 & - & - \\
Double spout and stirrup handle & 1 & $\mathbf{4}$ & $\mathbf{1}$ \\
Total & $\mathbf{1 3}$ & & Volcanic Fragments \\
\hline Surface modification & & 8 & 1 \\
Body sherds & Quartzose Feldspathic & Pyroxenic Placer & 2 \\
\hline Parallel-rib relief & 61 & 12 & 4 \\
Square relief & 56 & 15 & $\mathbf{7}$ \\
Diamond relief & 61 & $\mathbf{3 5}$ & \\
Total & $\mathbf{1 7 8}$ & & \\
\hline
\end{tabular}

the most common grain type (average 73\%). Opaque iron oxide is higher (average 17\%) than in local Karobo sherds (average 5\%), while other distinguishing characters include the presence of minor and deeply weathered biotite $(1 \%)$ and the absence of hornblende. The most likely source for the pyroxene sand of beach origin (PY temper), after comparison with Navua Delta sherds, is the nearby Navua Delta about $6.5 \mathrm{~km}$ from Karobo. The three sherds carry cross-hatch relief, and, like the majority of the Karobo assemblage, probably date to ca. 1500 BP.

A base sherd from a flat-based platter bearing leaf impressions (KAR-V2) contains a finegrained temper unlike the quartz-rich or pyroxene-rich variants. Opaque iron oxide is the most common mineral in the sherd $(46 \%)$, followed by plagioclase $(22 \%)$ and pyroxene $(11 \%)$. It contains biotite at $5 \%$ and oxyhornblende at $1 \%$, minerals not found in other Karobo sherds. Volcanic rock fragments are also present (13\%). This temper could have derived from the Navua Delta, although Dickinson considers that the plagioclase level is too low and the opaque iron oxide and pyroxene levels too high in comparison with the few sherds from Navua he has examined. In addition, hornblende (2\%) does not occur in any of the inferred Navua sherds so far examined.

An origin from Kadavu $65 \mathrm{~km}$ to the south is a possibility, considering the presence of oxyhornblende and biotite. However, other Kadavu sherds examined by Dickinson have a much greater proportion of plagioclase $(62-72 \%)$, and hornblende is the dominant pyribole (average $16 \%)$. Further, the Karobo sherd has a higher frequency of opaque iron oxide and volcanic rock fragments (in Kadavu sherds opaque iron oxide $=11-12 \%$ and $V R F=4 \%$ ), so the attribution of the Korobo sherd to Kadavu remains provisional. Nonetheless, once fired, the large platters, like those recorded from Karobo and Sigatoka Level 2 (Birks 1973), would have been difficult to transport, suggesting that the raw materials were taken to Karobo and the platters were manufactured at the site.

\section{Discussion of petrographic and optical results}

The megascopic examination of sectioned sherds has in each assemblage been able to identify sherds with non-local tempers. In this case, 'non local' means the temper sand is likely to have come from a location $6-10 \mathrm{~km}$ or more from where the sherd was found. The proportion of each excavated assemblage examined megascopically comprises between $2 \%$ and $13 \%$ of the total 
assemblage, with non-local tempers making up only $0.4 \%-1.5 \%$ of that amount. It is clear that potters at the three sites made use of locally available temper sands to manufacture ceramics, and there is no reason to suspect the large-scale importation of pottery. Temporal change in temper sources is identified at Ugaga, where the use of QF temper is limited to the Lapita phase, and at Navatu 17A, where the OL temper is associated with the oldest ceramics. The reason for a change in temper sand is unclear, and might result from site/location abandonment, a decline in the availability of a temper sand as a result of natural or anthropogenic environmental change, the imposition of social boundaries, and/or ceramic specialisation.

The majority of the non-local ceramics are decorated, and as with the dentate-stamped sherds found on Ugaga Island, likely to have been made with temper sands collected from Udu Point on Vanua Levu some $300 \mathrm{~km}$ away (a sherd from the Mulifanua Lapita site in Samoa [Dickinson 2006:118] is also thought to have Udu Point temper). At Navatu 17A and Ugaga, non-local sherds indicate transfer of ceramics from southern and eastern Viti Levu, with the possibility that temper sands from Kandavu were brought to Karobo to make large platters used to produce salt by evaporation of sea water (Burley 2005).

\section{Chemistry-based MD-ICP-MS}

The common practice of analysing clay and temper components in a sherd to examine prehistoric interaction can be problematic because of the heterogeneous composition of ceramics (Neff et al. 1988, 1989; Elam et al. 1992), and the possibility that the depositional environment has altered sherd composition (Ambrose 1993). To test whether chemistry-based MD-ICP-MS could be used to identify Lapita ceramics from individual islands and sites, Kennett et al. (2004) analysed sherds from Kulu Bay and Ugaga Island in Fiji, and compared results with those from analysed samples from Tonga (Vuki Mound) and New Ireland (Kamgot). Bivariate plots of Ho versus Mn separate Fijian sherds from Tonga and New Ireland, while Ga and Be differentiate Kulu Bay sherds from Ugaga Island ceramics.

The study also identified four sherds from Ugaga Island and two from Kulu Bay with anomalous compositions that were likely to represent imports to Beqa Island. Clear element distinctions between sites and islands led to the analysis of another 176 sherds of Lapita and post-Lapita age from nine assemblages excavated in the EPF. Samples were analysed with a Hewlett-Packard 4500 quadropole ICP-MS at California State University. Before analysis, sherd surfaces were abraded with a dremal tool and ground in a synthetic agate mortar, with sample digestion and ICP-MS processing as reported in Kennett et al. (2004:38). The abundance of 37 matrix and rare earth elements was measured (Be, Mg, Al, K, Sc, V, Cr, Mn, Fe, Co, Ni, Cu, Zn, Ga, Rb, Sr, Y, In, Cs, Ba, La, Ce, Pr, Nd, Sm, Eu, Gd, Tb, Dy, Ho, Er, Yb, Lu, Pb, Bi, Th and $\mathrm{U})$. Instrumental precision was $2-3 \%$ and detection limits for most elements were in the parts per billion ( $\mathrm{ppb}$ ) range.

The MD-ICP-MS analysis of pot sherds was designed to build on the petrology and optical temper results, as it was unclear whether the bulk composition of a sherd might produce erroneous results by identifying chemical outliers that are actually composed of different proportions of local clays and tempers. Another possibility is that sherds made with a non-local component could have been mixed with a local clay or temper, potentially obscuring the partially exotic origin of a ceramic from bulk composition. Sherds examined with petrology were used in the MD-ICP-MS study to determine whether it was a effective tool to investigate prehistoric interaction in Fiji. The first step was to determine whether MD-ICP-MS could correctly identify non-local sherds in a particular prehistoric pottery assemblage. Second, the utility of recent chemical characterisation techniques is that relatively large numbers of sherds can be analysed, 
making multi-assemblage comparisons viable. As reported by Kennett et al. (2004), sherds from Ugaga Island are chemically distinct from Kulu, but petrology results indicate transfer of pottery from Kulu Bay to Ugaga Island. The discrepancy suggests the depositional environment may be influencing element concentrations in pottery at either Kulu or Ugaga.

MD-ICP-MS identification of non-local sherds

The ability of MD-ICP-MS to discriminate non-local pottery in an assemblage was tested by analysing local and non-local sherds from Navatu, Karobo and Ugaga used in the petrographic study (Table 65). Descriptive statistics were calculated for the log-transformed MD-ICP-MS

Table 65. Sherd samples examined with petrography and MD-ICP-MS. The inferred origin of sherds is based on the identification of temper grains by Dickinson.

\begin{tabular}{|c|c|c|c|c|c|}
\hline Sherd code & Sherd & Decoration & Age group & Local & Inferred origin \\
\hline \multicolumn{6}{|l|}{ Navatu } \\
\hline NAV-1A & Body & Cross-hatch impressed & Post Lapita & Yes & Ba volcanics \\
\hline NAV-2A & Body & Plain & Post Lapita & Yes & Ba volcanics \\
\hline NAV-3A & Body & Plain & Post Lapita & Yes & Ba volcanics \\
\hline NAV-4A & Body & Cross-hatch impressed & Post Lapita & Yes & Ba volcanics \\
\hline NAV-7A & Body & Plain & Post Lapita & Yes & Ba volcanics \\
\hline NAV-9A & Body & Wavy impressed & Post Lapita & Yes & Ba volcanics \\
\hline NAV-109 & $\operatorname{Rim}$ & Punctate and finger impressed & Post Lapita & Yes & Ba volcanics \\
\hline NAV-1015 & $\operatorname{Rim}$ & Incised cross-hatching & Late prehistoric & No & South Viti Levu \\
\hline \multicolumn{6}{|l|}{ Ugaga } \\
\hline UGA-1A & Body & Irregular'dents' & ?Post Lapita & Yes & Vaga Bay, Beqa \\
\hline UGA-2A & Body & Incised & Lapita & Yes & Beqa unlocalised \\
\hline UGA-3A & Rim & Notched applied band & Lapita & Yes & Kulu Bay, Beqa \\
\hline UGA-4A & $\operatorname{Rim}$ & Plain & $?$ & Yes & Kulu Bay, Beqa \\
\hline UGA-8A & Body & Cross-hatch impressed & Post Lapita & Yes & Vaga Bay, Beqa \\
\hline UGA-10A & Body & Parallel impressed & Post Lapita & Yes & Beqa unlocalised \\
\hline UGA-11A & Body & Cross-hatch impressed & Post Lapita & Yes & Beqa unlocalised \\
\hline UGA-1106 & Body & Cross-hatch impressed & Post Lapita & No & South Viti Levu, ?Rewa Delta \\
\hline UGA-2671 & $\operatorname{Rim}$ & Tool notched collar & Lapita & Yes & Kulu Bay, Beqa \\
\hline \multicolumn{6}{|l|}{ UGA-2064 petro/ } \\
\hline UGA-906 ICP-MS & Rim & Dentate stamped & Lapita & No & Udu Point, Vanua Levu \\
\hline \multicolumn{6}{|l|}{ Karobo } \\
\hline KAR-1A & Double spout & Plain & Post Lapita & Yes & Wainimala drainage \\
\hline KAR-3A & Body & Cross-hatch impressed & Post Lapita & Yes & Wainimala drainage \\
\hline KAR-5A & Body & Plain & Post Lapita & Yes & Wainimala drainage \\
\hline KAR-8A & Body & Parallel impressed & Post Lapita & Yes & Wainimala drainage \\
\hline KAR-V2 & $\operatorname{Rim}$ & Leaf impressed & Post Lapita & No & ?Kadavu \\
\hline KAR-204 & Body & Cross-hatch impressed & Post Lapita & No & Navua Delta \\
\hline KAR-811 & Rim & Plain & Post Lapita & No & Navua Delta \\
\hline
\end{tabular}


element data (37 elements) from each site to identify outlier samples that might be exotic, followed by hierarchical cluster analysis (HCA), and multidimensional scaling (MDS) to test the robusticity of individual sample classifications. Discriminant function analysis (DFA) was used on the total sample of sherds from nine sites to locate potentially non-local sherds to a possible source area and to test group association. To examine the DFA placement of a sherd in an exotic assemblage, an additional HCA (Average Linkage) was run using the assemblage from which the non-local sherd was recovered against the possible source assemblage identified in the DFA. All statistical analyses were made with SPSS (Version 13). The hierarchical cluster analysis results for Navatu, Ugaga and Karobo are shown in Figures 139-141.

\section{Navatu MD-ICP-MS}

There were 31 sherds in the MD-ICP-MS sample from Navatu, and eight of these had been examined in thin-section by Dickinson, who had identified NAV-1015 as a late-prehistoric import from southern Viti Levu. The HCA of element data placed the Navatu sherds in two clusters, with two sherds (NAV-1015, NAV-2) separate from the main cluster and distinct from two sherds (NAV-19, NAV-25) on a separate branch of the dendrogram (Figure 139). The NAV-2 sherd associated with NAV-1015 is marked with wavy-impressions and comes from the

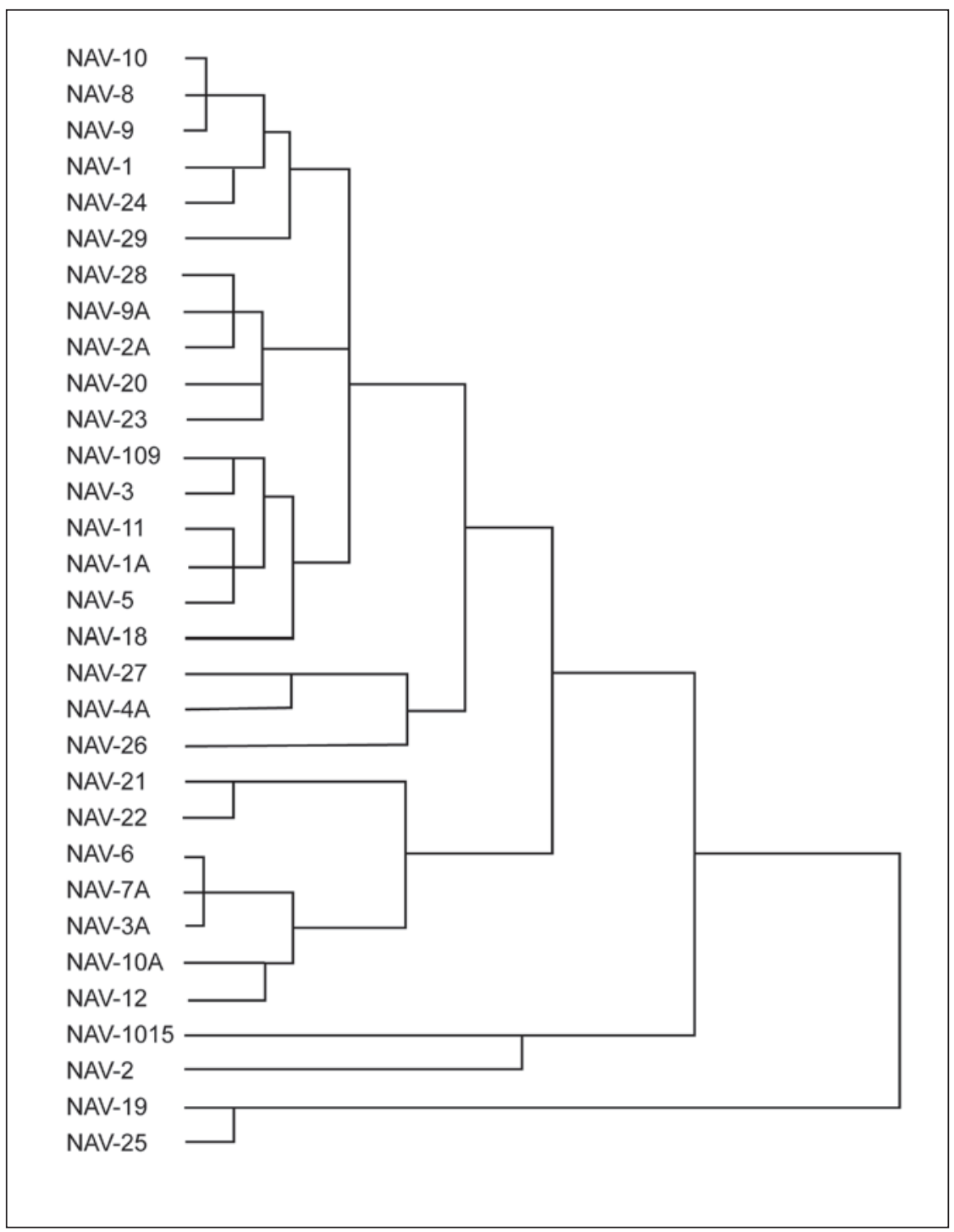

Figure 139. Cluster analysis of Navatu sherd composition determined with MD-ICP-MS. Outlier NAV-1015 was examined with petrology and MDICP-MS and identified as likely to originate from south Viti Levu. 
early Layer 4 occupation (Table 65). Similarly, NAV-19 and NAV-25, also possibly exotic to the site, were recovered from Layer 2 and Layer 4 respectively.

When entered as 'ungrouped cases' in a discriminant function analysis (DFA) containing all samples, NAV-1015 grouped closest to sherds from Volivoli in southwest Viti Levu, NAV-19 and NAV-25 clustered with sherds from Malaqereqere (southwest Viti Levu), and NAV-2 grouped with Natunuku ceramics (north coast Viti Levu). An HCA study of these sherds with those from Malaqereqere and Natunuku did not reveal a close connection between the non-local Navatu sherds and sherds from other sites. However, NAV-1015 was placed in the main group of Volivoli sherds in the HCA, indicating a possible origin for the sherd in the Volivoli area.

Both petrography and MD-ICP-MS were able to identify sherd NAV-1015 as of probably south-coast Viti Levu origin, with MD-ICP-MS indicating that pottery from the south and the west of Navatu was being brought to the site from ca.1500 cal. BP.

\section{Ugaga Island MD-ICP-MS}

The MD-ICP-MS sample from Ugaga consisted of 38 sherds, including 10 that had been examined in thin section by Dickinson (Table 65). Of these, eight were identified as deriving from Beqa Island, with two sherds containing the pyribole-rich temper (PY), three with the mixed-placer (MP) temper, and three with quartzose-feldspathic (QF) temper.

Sherd UGA-1106 has a quartzose temper likely to derive from the south coast of Viti Levu (or from an interior drainage leading to the south coast), and UGA-2064 is quartz-rich with significant plagioclase feldspars, suggesting derivation from the Udu Volcanic Group on the northern Vanua Levu Peninsula. Sherd UGA-906 was conjoined to UGA-2064, and was analysed with MD-ICP-MS. The HCA dendrogram clearly identified the exotic sherd UGA906/UGA-2064, which was sourced with petrography to the Udu Peninsula, along with a further 'anomalous' sherd UGA-1352 (Figure 140). However, UGA-1106, had a temper suggesting importation from the south coast of Viti Levu but was grouped with two sherds of probable Lapita age that may have been made on Beqa.

Sherds containing the PY, QF and MP tempers were spread across several of the main cluster groups, and did not group together on the basis of temper. This suggests the temper groups might in fact derive from more than one location. An alternative is that if most of the tempers derive from the same location, such as the QF temper, then either the quantity of temper has a significant impact on sherd composition, or a variety of clays were being used with the temper types.

The antiquity of samples was estimated in the HCA by decoration/vessel form attributes, as either 'Lapita' or 'post Lapita', with dentate-stamped and other distinctive-decoration/form sherds attributed to the 'Lapita' group, and impressed types of decoration to the 'post Lapita' group. Sherds that could not be placed in either group were assessed as '?Lapita' and '?post Lapita' based on vessel/rim form criteria that are less diagnostic than decoration. By age-class, both 'Lapita' and 'post Lapita' sherds formed discrete clusters, suggesting similar clay-temper mixes. For example, post-Lapita sherds UGA-68, 83, 96 and 114 grouped together, as did UGA-1A, 11A 14, while sherds UGA-661 to UGA-5A were all of Lapita age (excluding the post-Lapita non-local sherd UGA-1106). These sherds were made with components that were not apparently used by potters in post-Lapita times, and considering their frequency, were probably made with materials obtained on Beqa Island.

The Ugaga sherds are chemically varied. Two non-local sherds from Vanua Levu were able to be differentiated with MD-ICP-MS, but the technique was not able to clearly distinguish UGA-1106 as an import from southern Viti Levu. 


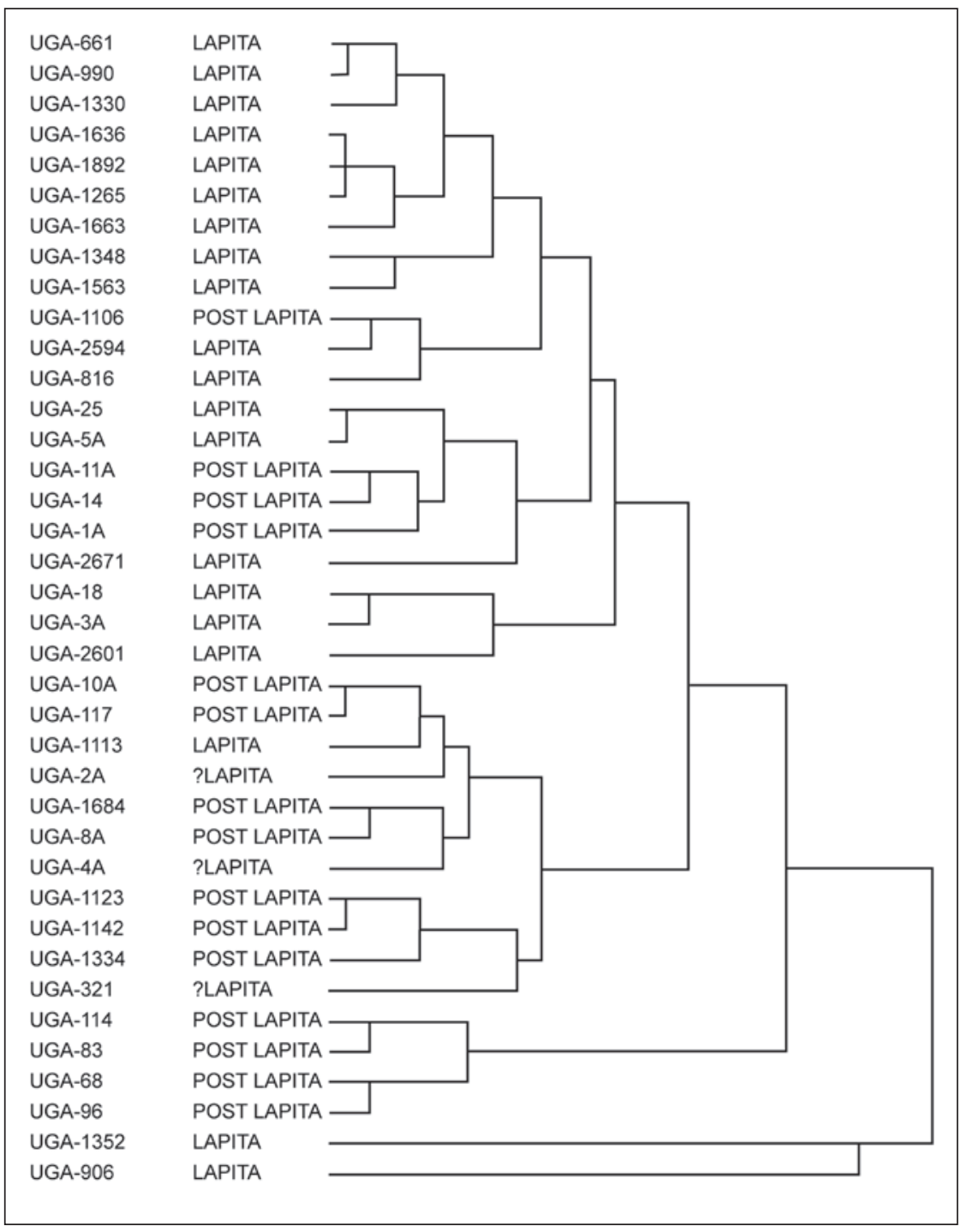

Figure 140. Cluster analysis of Ugaga sherd composition determined with MD-ICP-MS. UGA1106 was identified as of likely south Viti Levu origin by petrography. UGA-2064 was identified as of likely north Vanua Levu origin by petrography. Two sherds from the same vessel (UGA-906 and UGA2064) analysed with MD-ICP-MS are outliers.

\section{Karobo MD-ICP-MS}

The Karobo sample was the smallest of the three collections analysed, and consisted of 15 sherds. Seven of these had been examined in thin section by Dickinson (Table 65), who identified two sherds (KAR-204, 811) with temper sands that probably derived from the nearby Navua Delta, and one sherd (KAR-V2) as a potential import from Kandavu Island $65 \mathrm{~km}$ to the south. Univariate and multivariate statistics showed there was substantial variation within the Karobo sherd collection, displayed in the HCA dendrogram (Figure 141). The plot groups the three non-local sherds together (KAR-204, 811, V2), while sherds containing local temper (KAR$1 \mathrm{~A}, 3 \mathrm{~A}, 4 \mathrm{~A}, 5 \mathrm{~A}, 7 \mathrm{~A}, 8 \mathrm{~A})$ are distributed through the two main clusters. Without petrographic analysis, it is unlikely that KAR-204, 811, V2 would be identified as non-local on element results, although a larger sample might produce a better discrimination.

Sample KAR-9 is an outlier in the HCA (Figure 141), which nonetheless groups with the Karobo sample in a DFA using all analysed sherds. KAR-9 is a fragment of a platter marked on the base with leaf-impressions. The presence of platter sherds from two or three distinct locations at Karobo (Navua Delta, ?Kadavu, unknown) suggests possible importation of clay/ temper sands from several areas to manufacture the distinctive and fragile vessels that may have been used to produce salt. 


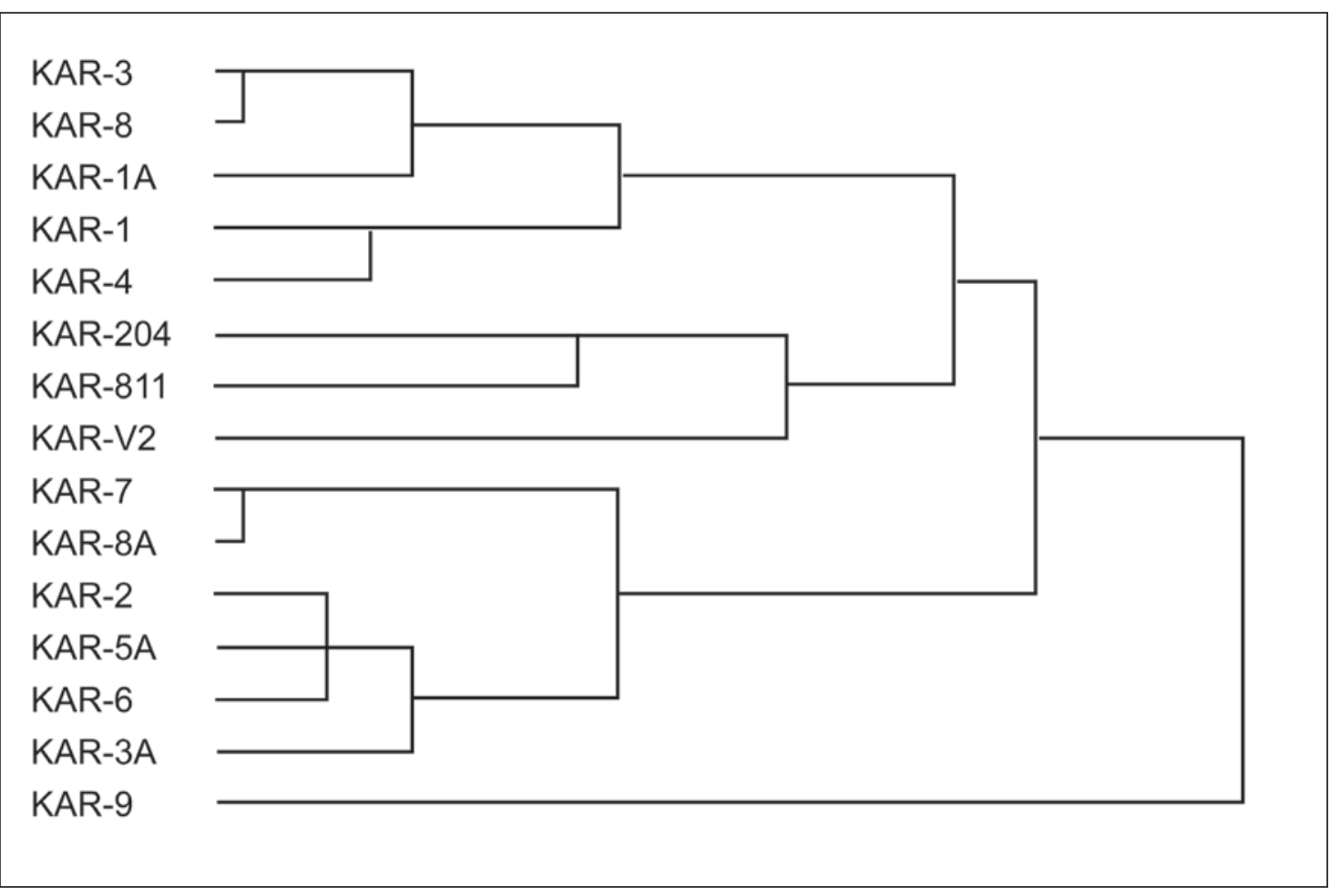

Figure 141. Cluster analysis of Karobo sherd composition determined with MD-ICP-MS. KAR-V2 and KAR-204 were identified as non-local by petrography (?Kadavu and Navua Delta).

\section{MD-ICP-MS of sherds from other sites}

The ability of MD-ICP-MS to identify non-local sherds in three assemblages was evaluated by investigating temper composition independently of chemistry-based MD-ICP-MS. Results demonstrate that significant outliers in the HCA plots of element data were non-local sherds in the case of Ugaga and Navatu, and although some ceramics identified with petrography as exotic were not easily identified in all MD-ICP-MS results, those from Ugaga and Navatu indicate that extreme outliers, like KAR-9 from Karobo, might well represent ceramic imports. The analysis was extended to six other sherd collections to identify potentially non-local sherds using the univariate and multivariate techniques used above.

\section{Viti Levu southwest coast and Beqa Island}

The three ceramic collections from Sigatoka, Malaqereqere and Volivoli were collected from coastal or near-coast sites in southwest Viti Levu, and the Kulu Bay sherds were from Beqa Island, about $10 \mathrm{~km}$ off the south Viti Levu coast (Figure 138).

The smallest assemblage analysed with MD-ICP-MS is made up of 10 surface sherds collected during EPF investigations at the Sigatoka Sand Dunes (Anderson et al. 2006). Based on decorative style, eight sherds bear impressed markings of post-Lapita age, one plain sherd is of indeterminate age, and a lug sherd similar to those identified by Birks (1973) probably dates to the late-Lapita era ca. $2600 \mathrm{cal}$. BP. HCA shows one cross-hatch impressed sherd (SIG-6) is an outlier. Discriminant function analysis places this sherd with the Navatu sample, but an HCA limited to only the Navatu and Sigatoka samples shows SIG-6 is an outlier from both sites, and Navatu is unlikely to be the sherd source.

The Malaqereqere sherd collection consists of 14 plain body sherds, all of which appear to date to ca. $750 \mathrm{cal}$. BP or later. In the HCA, there is a main cluster containing 13 sherds with 
one outlier, MAL-2, from 50-60 cm depth. Additional HCA and DFA of this sherd with other south-coast ceramics included the sample within the range, suggesting that MAL-2 might not be a long-distance import from beyond the south coast.

Volivoli II and Volivoli III are two adjacent rock shelters, and a combined sample of 23 plain sherds from the two excavations was used in the HCA. Two sherds from Volivoli III were identified as outliers (VOLI-1, VOLI-4). A DFA of all sherds was then run, which placed the two Volivoli sherds, along with another sample (VOLI-3), with ceramics from nearby Sigatoka. An additional HCA of Volivoli versus Sigatoka demonstrated the expected compositional similarity of sherds from Sigatoka and Volivoli to one another, and confirmed the outlier status of the probable non-local sherd, SIG-6.

From Kulu Bay on Beqa Island, 26 sherds were analysed with MD-ICP-MS. Most are stylistically of Lapita age, with only three impressed post-Lapita sherds. The HCA identified two main clusters in the chemical data, and DFA of two cluster outliers (KULU-3, KULU-27) placed the ungrouped cases with ceramics from the Votua site in the Lau Group. The linkage was tested with an HCA of Kulu Bay and Votua sherds which did not place either of the two Kulu sherds with the Votua ceramics. The two sherds might be non-local, or might represent local variation in the Beqa Island ceramic suite.

\section{Viti Levu north coast and Lau}

In the HCA, 30 Natunuku sherds were placed on a main branch of the dendrogram, separate from two sherds. One of the latter is a dentate-stamped and notched Lapita rim sherd (NAT16), and the other (NAT-28) is a plain rim of indeterminate age. Further analysis with DCF and HCA suggested these samples may have been imports, or their composition reflects local variation in clays and tempers in the vicinity of Natunuku. When labelled by indicative sherd age, the dendrogram spread of Lapita pottery at Natunuku suggests significant compositional variation, suggesting clays and tempers were collected from several local sources.

Ceramics from the Lapita site at Votua site on Mago Island dating to $2750 \mathrm{cal}$. BP were examined, along with three post-Lapita sherds bearing impressed markings from the nearby limestone shelter site of Sovanibeka. The dendrogram located a 'wavy' impressed sherd from

Sovanibeka on a separate branch to other samples, with VOT-32 also located away from the main cluster group. An all-sample DFA placed VOT-32 with other Votua-Sovanibeka sherds, and located the SOV-4 sherd with those from Karobo in southern Viti Levu. An HCA of Votua and Karobo sherds identified the compositional similarity of SOV-4 to three Karobo sherds (KAR-2, 3A, 5A, 6), indicating a possible south Viti Levu origin for the SOV-4 sherd.

\section{Inter-site comparison: Ugaga Island and Kulu Bay}

MD-ICP-MS results from 219 sherds from nine sites identified a relatively small number of sherds as probable imports. These include the unambiguous non-local sherds (NAV-1015, NAV-2, NAV-19, NAV-25, UGA-906, UGA-1352, SIG-6, SOV-4), as well as sample outliers like KAR-9, NAT-16 and NAT-28 that might well be imports. Moreover, the chemical data displayed coherent patterns when sherd age was considered, particularly at Ugaga, where clusters of Lapita and post-Lapita sherds were recognised. However, non-local sherds identified with petrology, such as UGA-1106, KAR-204, KAR-811 and KAR-V2, were not seen to be distinct from presumed locally made sherds in some analyses.

At the assemblage level, chemistry-based MD-ICP-MS was able to discriminate non-local sherds from the majority, which are inferred to have been made with locally available materials. It is reasonable to expect that an inter-site analysis, then, should differentiate sherds from distinct 
localities because the chemical signature of locally produced sherds from each site was able to identify statistical 'non-local' outliers.

Indeed, DFA can separate ceramic samples from nine sites (combining samples from Votua and Sovanibeka, and Volivoli II and Volivoli III), suggesting the feasibility of employing larger samples from many more archaeological sites to comprehensively investigate the movement of prehistoric pottery in Fiji over 3000 years (Figure 142).

However, while the MD-ICP-MS results from Ugaga Island and Kulu Bay show significant chemical differences between the two sherd collections, petrographic work by Dickinson on pottery from Kulu Bay and Ugaga Island and sherds collected from Beqa Island by Crosby (1988) indicated that the main temper groups present in the Ugaga assemblage were probably collected from places on Beqa Island, including Kulu Bay.

Sherds from Ugaga Island and Kulu Bay with the QF temper had mineralogical characteristics that were: 'not shared jointly to [a] similar degree by any other tempers known to date from either Fiji or elsewhere, and provisionally stand as a potentially unique fingerprint of tempers derived from the vicinity of Kulu Bay' (Dickinson 1997). A comparison of the QF-tempered sherd UGA-2671 with the mineralogy of three QF sherds from Kulu Bay is shown in Table 66, and the close similarity is evidence that both were made with temper sands collected from Kulu Bay.

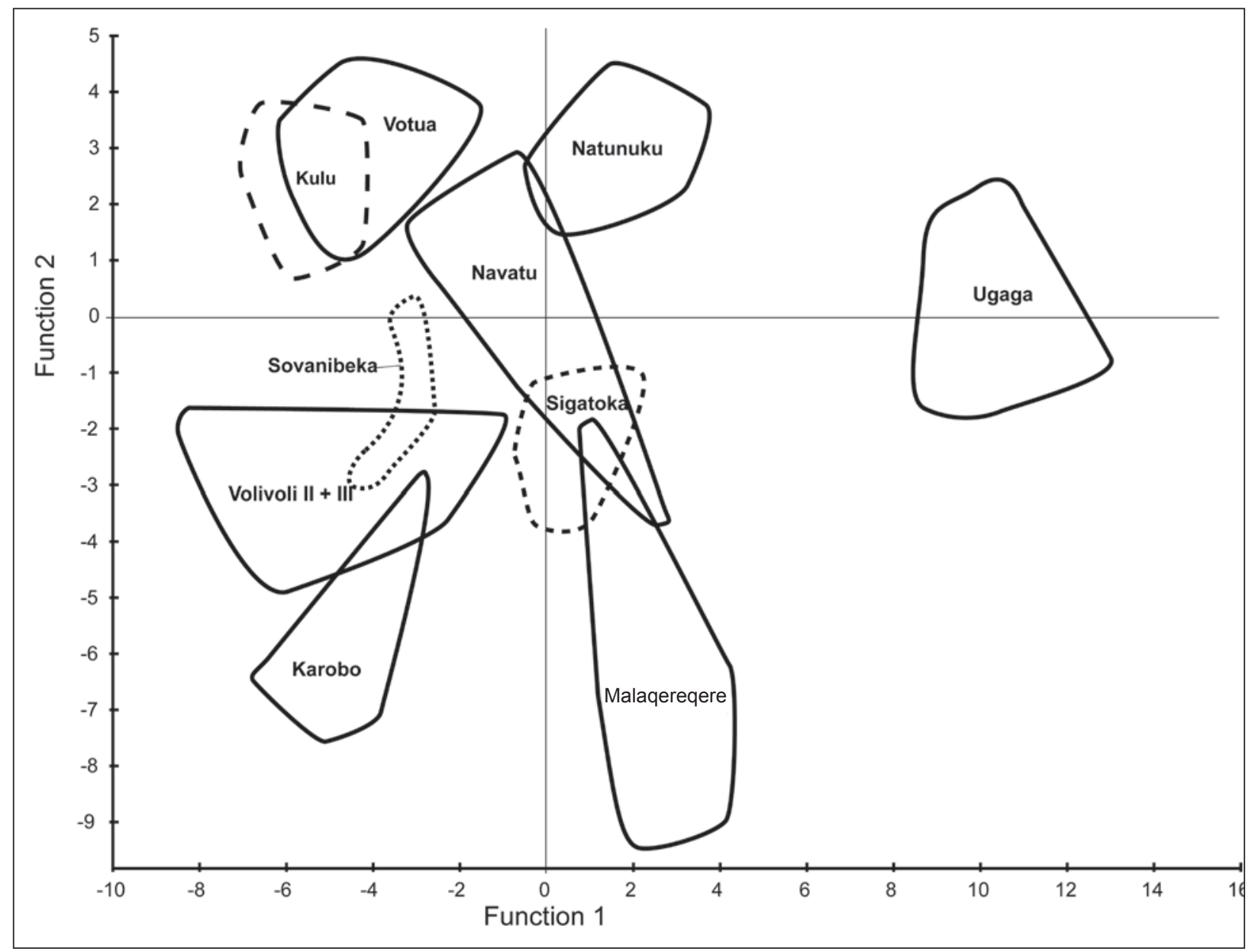

Figure 142. Discriminant function analysis of pot sherds from nine sites (Natunuku, Volivoli II+III, Malaqereqere, Sigatoka, VotuaSovanibeka, Ugaga, Kulu Bay, Karobo, Navatu). The two functions account for $72.2 \%$ of variance. Note that compositional boundaries include local and non-local sherds. Note the separation between Kulu Bay and Ugaga Island ceramics and also between Votua and Sovanibeka sherds, suggestive of post-depositional change in sherd composition. 
Table 66. Comparison of a Lapita shed from Ugaga Island with the QF temper compared to average grain counts from three Lapita-age QF-tempered sherds from Kulu Bay.

\begin{tabular}{lcc}
\hline Grain type & UGA-2671 & Kulu Bay (N=3) \\
\hline Quartz & 7 & 8 \\
Plagioclase & 41 & 41 \\
K-feldspar & 2 & 2 \\
Pyroxene & 12 & 4 \\
Hornblende & 2 & 6 \\
Opaque & 4 & 6 \\
Epidote & 2 & 2 \\
Biotite & 1 & 1 \\
Microphanerite & 4 & 10 \\
Microlitic VRF & 18 & 14 \\
Glassy VRF & 7 & 8 \\
\hline
\end{tabular}

VRF $=$ Volcanic rock fragment

The two other temper groups found in Ugaga ceramics, PY and MP, are also likely to derive from Beqa Island, and a common origin for a proportion of ceramics from Ugaga and Kulu is strongly implied, considering the similar mineralogy of the tempers, the proximity of the two locations to one another in the Lapita period, and the absence of suitable pottery-making clays on the small islet of Ugaga.

The discrepancy between MD-ICP-MS and petrology results is shown in an MDS diagram of Ugaga and Kulu assemblages (Figure 143), and was repeated in HCA (centroid, Ward's, nearest neighbour), regardless of whether non-local sherds were removed from the analysis, or whether the most influential elements responsible for group separation were omitted. Restriction of the Ugaga sample to seven sherds identified with the QF temper thought to originate from Kulu Bay also failed to reveal any similarity to sherds from Kulu Bay.

The elements most influencing group separation include Be, Co, Ni, Cu, Zn, Ga, In, Cs, $\mathrm{Ba}, \mathrm{Lu}$ and $\mathrm{Bi}$. The elements are significantly correlated with each other (Pearson Correlation Significance (two-tailed) at the 0.05 level), except for Co versus Lu. Compared with assemblages with a reasonable number of sherd analyses (Volivoli II+III, Votua + Sovanibeka, Navatu, Natunuku, Ugaga), Kulu sherds have mean element levels that were elevated in $\mathrm{Cu}, \mathrm{Zn}, \mathrm{Ga}$, Cs, Ba, La, Ce, Pr, Nd, Sm, Eu and Gd. Of these, Cu, Zn and Ga are related transition metals subject to oxidisation, while most of the remainder belong to the Lanthanide rare earth elements (LREE).

The elevation of clusters of elements, particularly the LREE, suggests either the enrichment/ stabilisation of the elements in ceramics recovered in the wet and sticky clay at Kulu Bay, or the depletion of these elements in sherds deposited at other locations. The Kulu Bay sherds were washed in saltwater after excavation, which might affect element concentration from the subsequent precipitation of mineral salts. The loss of $\mathrm{Ca}$ in sherds has been recorded when $\mathrm{CaCO}_{3}$, as shell-temper, is eroded from ceramics (Descantes et al. 1998). However, only a portion of the Ugaga Island and Kulu Bay sherds contained shell temper and it appears that burial conditions at one or both of the sites altered the chemical composition of the pottery in ways that are as yet unclear. In a study of Mycenaean pottery, alkali elements and some 


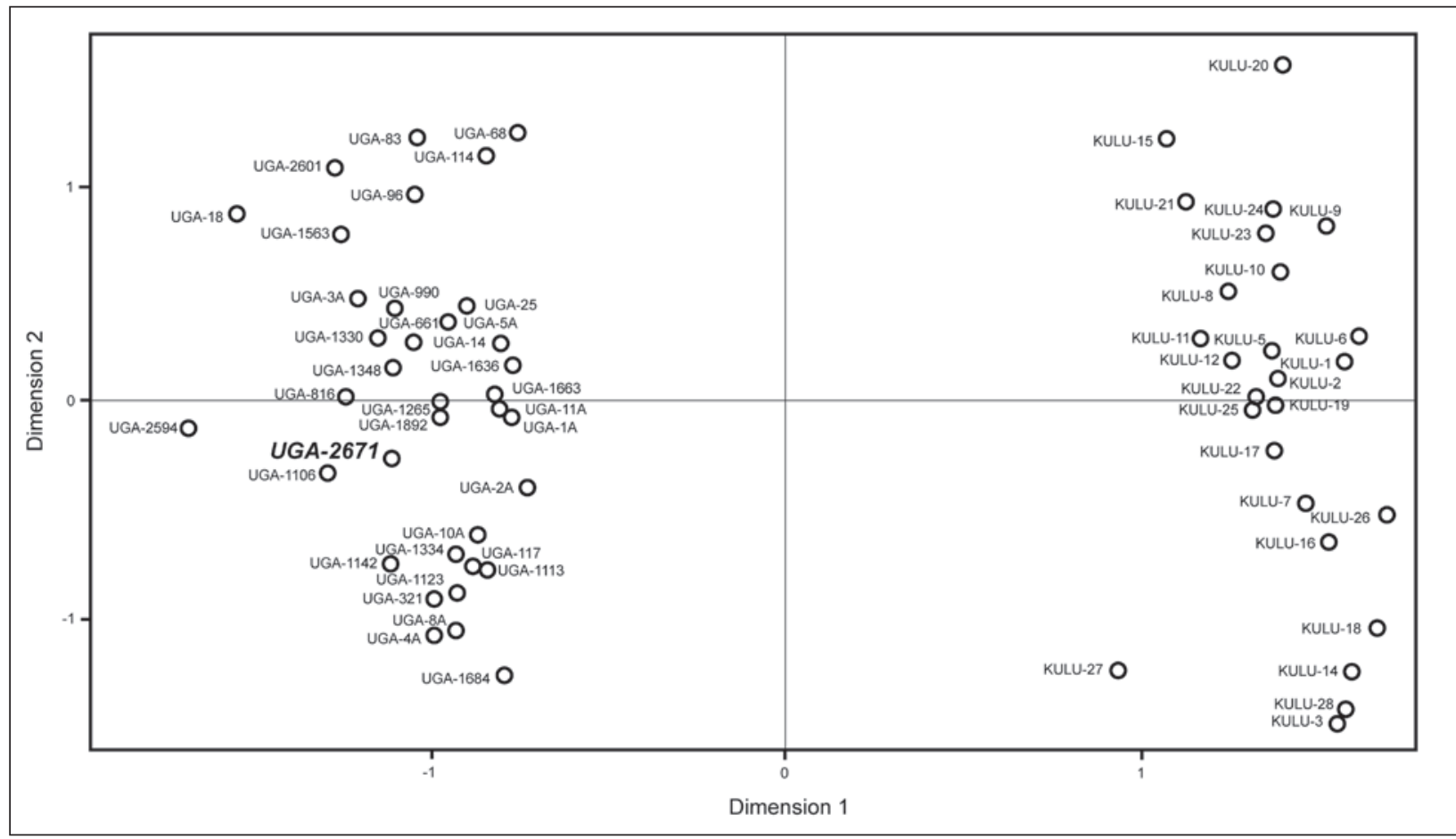

Figure 143. MDS diagram of sherd composition from Ugaga Island and Kulu Bay determined with MD-ICP-MS (37 elements). Petrographic analysis indicates that sherds from Kulu Bay were brought to Ugaga Island and this was also indicated by the similarity in vessel form and decoration and site proximity. Geochemical analysis, however, shows no overlap between the two assemblages, suggesting that sherd composition has been altered by the burial environment. Sherd UGA-2671 from Ugaga Island has a mineral suite almost identical to QF tempered sherds from Kulu Bay, but does not group with any Kulu Bay sherds.

REE were found to have been leached by burial conditions, but instances of post-burial change in prehistoric sherds is overall comparatively rare (Schwedt et al. 2004). Alteration of alkali metals post-burial, especially $\mathrm{Cs}, \mathrm{Na}, \mathrm{K}, \mathrm{Rb}$ and $\mathrm{P}$, has also been recognised in other studies, but generally most REEs in ceramics have not been recorded as being significantly altered by the depositional environment (Freestone et al. 1985; Garrigos et al. 2001; Garrigos et al. 2002).

There is no parallel in the literature for the deviation in ceramic composition recorded between the Ugaga and Kulu Bay sherds. If the petrology results are accurate, then the MD-ICPMS results may be differentiating ceramic assemblages that were made with similar materials, and at the end of their use-life interred in unique burial environments that have altered the chemical composition of sherds. Element variation in pottery can occur because of chemical and mineralogical variation in the clay deposit (Elam et al. 1992; Druc and Gwyn 1998), the addition and subtraction of elements during the manufacturing phase (Carpenter and Feinman 1999), and post-depositional alteration and contamination of the sherds (Garrigos 1999). Pottery use can also enhance element concentrations (Hally 1986).

Post-depositional alteration of ceramics is suggested in the current data, but the conclusion needs to be tested by studies combining petrology and MD-ICP-MS of prehistoric ceramics known to have been made in one place and interred elsewhere. In Fiji, such a comparison might usefully focus on pottery produced in the Rewa Delta of Viti Levu, and found in many parts of the archipelago, to examine how the depositional environment affects sherd composition. Another line of investigation would be to analyse sediments from Kulu Bay and Ugaga Island to determine whether chemical differences in the soil mirror ceramic element concentrations observed in pot sherds, and the use of LA-ICP-MS on sherd clays to investigate whether diagenesis is primarily affecting the concentration of elements in sherd clay. The latter possibility 
may be significant, as Cochrane (2004) used LA-ICP-MS to target sherd clay in an analysis of ceramic interaction from the Yasawa Islands.

The results of the MD-ICP-MS study demonstrate that it is a useful technique to investigate intra-site ceramic variation, as several outliers examined with petrology were confirmed to be non-local. However, uncertainties remain about the reliability of a multi-site study because the Ugaga ceramics were shown to have a distinct composition from the pottery from Kulu Bay sample, even though some pottery analysed was almost certainly made with similar clay and temper.

\section{Ceramic interaction patterns}

The different methods used to examine sherd constituents (petrology, megascopic and chemical) confirm the long-distance movement of pottery in the Fiji Islands in the Lapita period, with ceramics on Ugaga Island that probably derive from Vanua Levu, and in the post-Lapita era, with an impressed sherd on Mago Island that grouped with ceramics from southern Viti Levu. It is difficult to draw conclusions about the frequency of interaction over time considering the relatively small size of the sherd samples analysed from each site. During the Lapita period, it is evident a variety of clays and tempers were used to manufacture ceramics, given the chemical diversity observed in sherds from Ugaga and Natunuku. This is consistent with high rates of population mobility in the islands of Fiji during Lapita colonisation that is likely to have resulted in potters having to use locally available, and at times sub-optimal, clay and temper. Significant differences in the quantity of temper grains added by potters to clay suggest a high rate of experimentation, consistent with this.

A byproduct of high mobility is a higher rate of material-culture production and discard than at permanently occupied settlements (Schiffer 1972). This might be significant for Lapita ceramics as pottery made with new combinations and types of raw materials should experience greater amounts of manufacture and use failure, in addition to significant ceramic discard and breakage from canoe travel and community relocation. A further consequence of local ceramic production coupled with frequent site relocation and site abandonment is the caching of valued material culture items. The transport of artefacts with particular functional attributes, as well as artefacts whose value was connected to the belief system, is also anticipated, and several nonlocal Lapita sherds were from decorated vessels.

In post-Lapita times the movement of pottery continued, but there was reduced chemical variability as the overall rate of community mobility declined and populations were aggregated in permanent/semi-permanent settlements. One exception to this appears to be the coastal site of Karobo where groups from different areas appear to have been making flat-based platters, possibly to extract salt from seawater.

The presence of non-local pottery in post-Lapita sites might be the result of formal intergroup events (trade and exchange, marriage, death, title bestowal) rather than community mobility, as was suggested to have been common during the colonisation phase. Reduced community mobility and relatively stable access to quality clay and temper sources could lead to full, or partial, craft specialisation, as in the case of Rewa ceramics that were transported widely in late prehistory as well as the production of large pots on Kadavu Island (Hunt 1979).

In the Yasawa Islands, sherd clays analysed with LA-ICP-MS indicated that the spatial extent of interaction in the western Fiji Islands (Mamanuca-Yasawa Islands) contracted after 1000 BP (Cochrane 2004). The increasing frequency of pottery from the northern Yasawas in upper levels of the Y2-39 rock shelter in the south of the Yasawas suggests, if the element data is reliable, increased importation of pottery in late prehistory, although exotic sherds interpreted as 
being from outside the Yasawas-Mamanucas were also present. The possible demise, or reduced emphasis, on pottery production in islands to the south of the Yasawas, such as the Mamanucas and Malolo (no sherds were examined by Cochrane (2004) from these islands), and the possibility of a greater emphasis on pottery manufacture in the northern islands of the Yasawsas suggests informal or part-time craft/product specialisation. Highly valued pottery from Rewa was moved through the Fiji Islands in late prehistory, and was used by chiefs (Best 1984:606611), while other small islands in the proto-historic era were associated with particular products and crafts (see also Hooper 1982; Young 1982). There are hints that the geographic association of some islands with particular products used in trade and exchange relationships also occurred in the Yasawas, which were known for the quality of their sail mats that were sought after by Tongans in the 19th century (Derrick 1974:121). Rather than reduced interaction in west Fiji, as surmised by Cochrane (2004), the compositional data he obtained may be tracking change in pottery production as a result of craft specialisation, that in turn is related to the development of complex Fijian chiefdoms in late prehistory whose influence spanned the archipelago.

Chemical analysis of prehistoric pottery can reveal the spatial extent of interaction and variation in rates of community mobility, when ceramics accompany people to a new destination or are used extensively in trade and exchange networks. Compositional data from ceramics will not specify interaction patterns accurately when ceramics manufactured at a particular location were produced primarily for domestic requirements and pottery was not used in exchange networks.

The term 'interaction', which can be defined as 'contact between individuals in a population' (Cochrane and Neff 2006:379), does not take into account the likelihood of increased community mobility during the colonisation era, which correlates, in terms of ceramic production, with increased compositional variability within a site assemblage. This variability is generally interpreted as the result of 'interaction' rather than the effects of community mobility and relocation. For instance, a Lapita group travelling from Viti Levu to islands in the Lau Group could leave ceramic debris at several temporarily occupied locations from pots made at several islands, even though there was no 'interaction' or contact with individuals from outside the voyaging community.

When a community is tethered to a location, as is argued to occur more frequently in the post-colonisation era, interaction at the inter-group level is suggested to have increased in importance, but exactly how pottery was incorporated into community events and activities in prehistory is difficult to determine. A large volume of non-local pottery suggests regular contact and exchange between post-Lapita groups, while small amounts of non-local pottery indicate that ceramics were not an important exchange item. Vessels may have been transported to a location as food and water containers, or were kin-related gifts representing visits between extended families rather than formal inter-group exchanges. In addition, while trade and exchange networks involving pottery or stone tools should be archaeologically identifiable, not all communities necessarily engaged in the production of these items, and their interaction histories may not be deduced confidently from the compositional study of ceramics. In such instances, details of ceramic form and decoration can supplement compositional data to refine our views about prehistoric population connectivity within and between Fijian islands. 


\section{References}

Ambrose, W.R. 1993. Pottery raw materials: Source recognition in the Manus Islands. In: Spriggs, M., Yen, D.E., Ambrose, W., Jones, R., Thorne, A. and Andrews, A. (eds), A community of culture. The people and prehistory of the Pacific, pp. 206-217. Department of Prehistory, Research School of Pacific Studies, Australian National University.

Anderson, A., Roberts, R., Dickinson, W., Clark, G., Burley, D., De Biran, A., Hope, G. and Nunn, P. 2006. Times of sand: Sedimentary history and archaeology at the Sigatoka Dunes, Fiji. Geoarchaeology 21: 131-154.

Aronson, K.F. 1999. A compositional analysis of ceramics from the Qaranicagi rockshelter: Implications for exchange. Unpublished MA thesis, University of Hawaii.

Band, R.B. 1968. The geology of southern Viti Levu and Mbengga. Geological survey of Fiji, Bulletin No. 15.

Bentley, R.A. 2000. Provenience analysis of pottery from Fijian hillforts: Preliminary implications for exchange within the archipelago. Archaeology in Oceania 35: 82-91.

Best, S. 1984. Lakeba: the prehistory of a Fijian Island. Unpublished PhD thesis, Department of Anthropology, University of Auckland.

Birks, L. 1973. Archaeological excavations at Sigatoka dune site, Fiji. Bulletin of the Fiji Museum No.1.

Burley, D. 2005. Mid-sequence archaeology at the Sigatoka Sand Dunes with interpretive implications for Fijian and Oceanic culture history. Asian Perspectives 44(2): 320-348.

Clark, G. and Sorovi-Vunidilo, T. 1999. Fijian double-spouted vessels. Domodomo 11: 6-14.

Carpenter, A.J. and Feinman, G.M. 1999. The effects of behaviour on ceramic composition: Implications for the definition of production localities. Journal of Archaeological Science 26: 783-796.

Cochrane, E.E. 2004. Explaining cultural diversity in Ancient Fiji: The transmission of ceramic variability. Unpublished $\mathrm{PhD}$ thesis, University of Hawaii.

Cochrane, E.E. and Neff, H. 2006. Investigating compositional diversity among Fijian ceramics with laser ablation-inductively coupled plasma-mass spectrometry (LA-ICP-MS): Implications for interaction studies on geologically similar islands. Journal of Archaeological Science 33: 378-390.

Crosby, A. 1988. Beqa: archaeology, structure and history in Fiji. Unpublished MA thesis, Department of Anthropology, University of Auckland.

Curtis, G.H. 1951. Appendix I. Petrography of pottery. In: Gifford, E.W. Archaeological excavations in Fiji, pp. 239-241. University of California Anthropological Records 13: 189-288.

Derrick, R.A. 1974. A history of Fiji, Government Press, Suva.

Descantes, C., Neff, H., Glascock, M.D. and Dickinson, W.R. 1998. Chemical characterization of Micronesian ceramics through neutron activation analysis. Journal of Archaeological Science 28: $1185-1190$.

Dickinson, W.R. 1971. Petrography of some sand tempers in prehistoric pottery from Viti Levu, Fiji. Final report No. 2. Records of the Fiji Museum 1: 108-121.

Dickinson, W.R. 1973. Appendix 1. Sand temper in prehistoric potsherds from the Sigatoka Dunes, Viti Levu, Fiji. In: Birks, L. Archaeological excavations at Sigatoka dune site, Fiji, pp. 69-73. Bulletin of the Fiji Museum No.1.

Dickinson, W.R. 1980. Appendix B. Foreign temper at Yanuca on Viti Levu. In: Hunt, T.L. Toward Fiji's past: archaeological research on southwestern Viti Levu, pp. 216-217. Unpublished PhD thesis, University of Auckland.

Dickinson, W.R. 1997. Sand tempers in prehistoric sherds from Kulu Bay, Beqa Island, Fiji. Unpublished Petrographic Report WRD-161 (15 November 1997).

Dickinson, W.R. 1998. Petrographic temper provinces of prehistoric pottery in Oceania. Records of the Australian Museum 50: 263-276.

Dickinson, W.R. 2001. Petrography and geological provenance of sand tempers in prehistoric potsherds from Fiji and Vanuatu: South Pacific. Geoarchaeology 16: 275-322. 
Dickinson, W.R. 2006. Temper sands in prehistoric Oceanian pottery: Geotectonics, sedimentology, petrography, provenance. The Geological Society of America Special Paper 406.

Druc, I.C. and Gwyen, Q.H.J. 1998. From clay to pots: a petrographical analysis of ceramic production in the Callejon de Huaylas, North-Central Andes, Peru. Journal of Archaeological Science 25: 707-718.

Elam, M.J., Carr, C., Glascock, M.D. and Neff, H. 1992. Ultrasonic disaggregation and instrumental neutron activation analysis of textural fractions of Tucson Basin and Ohio Valley pottery. In: Neff, H. (ed), Ceramic characterization of ceramic pastes in archaeology. Monographs in World Archaeology No. 7, Prehistory Press, Madison, Wisconsin.

Freestone, I.C., Meeks, N.D. and Middleton, A.P. 1985. Retention of phosphate in buried ceramics: An electron microbeam approach. Archaeometry 27: 161-177.

Garrigos, J.B. 1999. Alteration and contamination of archaeological ceramics: The perturbation problem. Journal of Archaeological Science 26: 295-313.

Garrigos, J.B., Kilikoglou, V. and Day, P.M. 2001. Chemical and mineralogical alteration of ceramics from a late Bronze Age kiln at Commos, Crete: The effect on the formation of a reference group. Archaeometry 43: 349-372.

Garrigos, J.B, Mommsen, H. and Tsolakidou, A. 2002. Alteration of Na, K and Rb concentrations in Mycenean pottery and a proposed explanation using X-ray diffraction. Archaeometry 44: 187-198.

Gifford, E.W. 1951. Archaeological excavations in Fiji. University of California Anthropological Records 13: 189-288.

Hally, D.J. 1986. The identification of vessel function: A case study from northwest Georgia. American Antiquity 51: 267-295.

Hunt, C. 1979. Fijian pottery and the manufacture of cooking pots on Kadavu Island. The Artefact 4: $27-35$.

Hooper, S.P. 1982. A study of valuables in the Chiedfdom of Lau, Fiji. Unpublished PhD thesis, University of Cambridge.

Kennett, D.J., Anderson, A., Cruz, M.J., Clark, G. and Summerhayes, G. 2004. Geochemical characterization of Lapita pots via Inductively Coupled Plasma Mass Spectrometry (ICP-MS). Archaeometry 46: 35-46.

Neff, H., Bishop, R.L. and Sayre, E.V. 1988. A simulation approach to the problem of tempering in compositional studies of archaeological ceramics. Journal of Archaeological Science 15: 159-172.

Neff, H., Bishop, R.L. and Sayre, E.V. 1989. More observations on the problem of tempering in compositional studies of archaeological ceramics. Journal of Archaeological Science 16: 57-69.

Petchey, F. 1995. Archaeology of Kudon: archaeological analysis of Lapita ceramics from Mulifanua, Samoa and Sigatoka, Fiji. Unpublished MA thesis, Department of Anthropology, University of Auckland.

Schiffer, M.B. 1972. Archaeological context and systematic context. American Antiquity 37: 157-165.

Schwedt, A., Mommsen, H. and Zacharias, N. 2004. Post-depositional element alterations in pottery: Neutron activation analyses of surface and core samples. Archaeometry 46: 85-101.

Seeley, J.B. and Searle, E.J. 1970. Geology of the Rakiraki district, Viti Levu, Fiji. New Zealand Journal of Geology and Geophysics 13: 52-71.

Young, J. 1982. The response of Lau to foreign contact: An interdisciplinary reconstruction. The Journal of Pacific History XVII: 29-50. 